\section{'Amas mercenárias': o discurso dos doutores em medicina e os retratos de amas - Brasil, segunda metade do século XIX}

\section{'Mercenary wet-nurses': the discourse of medical doctors and portraits of the wet-nurses - Brazil in the second half of the 19th century}

Sandra Sofia Machado Koutsoukos

Bolsista Fapesp e pós-doutoranda no Departamento de Multimeios, Mídia e Comunicação/Universidade Estadual de Campinas Av. San Conrado, 2067

13104-164 - Campinas - SP - Brasil

sandrakoutsoukos@hotmail.com

Recebido para publicação em agosto de 2007 Aprovado para publicação em junho de 2008.
KOUTSOUKOS, Sandra Sofia Machado. 'Amas mercenárias': o discurso dos doutores em medicina e os retratos de amas - Brasil, segunda metade do século XIX. História, Ciências, Saúde Manguinhos, Rio de Janeiro, v.16, n.2, abr.-jun. 2009, p.305-324.

Resumo

Explora o tema das amas-de-leite em fotografias e teses dos doutores em medicina da segunda metade do século XIX. Os médicos de então condenavam o emprego indiscriminado de amas-deleite e tentavam estimular a construção da imagem da 'nova mãe', que devia amamentar seus próprios filhos. Abordam-se a complexidade do assunto amamentação (por mãe, ama, animal ou objeto) na época e os problemas dele decorrentes para as partes envolvidas: o bebê branco, o bebê negro, a ama, a mãe do bebê branco, a família senhorial abrangente e os doutores em medicina. Destacam-se fotos de amas com crianças, em atitude que se pretendia 'positiva', a demonstrar harmonia e afeto e, aparentemente, em contradição com os debates que envolviam seu emprego.

Palavras-chave: teses de medicina; amas-de-leite; retratos de amas; século XIX; Brasil.

Abstract

The article explores the theme of wet-nurses using photographs and theses of medical doctors during the second half of the 19th century. The doctors at that time condemned the indiscriminate use of wetnurses and tried to encourage construction of the 'new mother' image, one who ought to breast feed her own children. They approached the complexity of the feeding subject (by mother, wet-nurse, animal or object) at that time and the problems arising from it for the parties involved: the white baby, the black baby, the wet-nurse, the mother of the white baby, the seignorial family involved and medical doctors. Photos are highlighted of wet-nurses with children in an attitude that was intended to be 'positive', to demonstrate harmony and affection and, apparently, contradicting the debates regarding them.

Keywords: Medical theses; Brazil; 19th century; wet-nurses; portraits of nursemaids. 
$\mathrm{Q}$ uando uma família precisava dos serviços de uma ama-de-leite, não havendo alguma disponível em meio a seus próprios escravos, recorria a vizinhos e conhecidos, que poderiam indicar ama já conhecida e com referências. Como último recurso, talvez lançasse mão dos numerosos anúncios nos jornais locais. Para ajudar na escolha da 'mercadoria', ou seja, na compra ou aluguel de escrava para esse fim, alguns trabalhos orientavam sobre como a 'peça' deveria ser examinada, em que detalhes o interessado deveria manter a atenção para evitar o risco de calotes. ${ }^{1}$ No Brasil, a partir de meados do século XIX, as constantes epidemias de febre amarela e cólera que assolavam as cidades aumentaram a pressão, por parte dos médicos higienistas, para que os bebês brancos passassem a ser amamentados por suas próprias mães. Além da tentativa dos médicos de criar a 'nova mãe', ou a 'mãe higiênica', que se encarregaria dos cuidados de seus filhos e seria aliada dos profissionais da saúde, surgiram na década de 1880 algumas propostas de regulamentação do serviço de criadas e amas-de-leite livres ou escravas, que passariam periodicamente por exames médicos, em clínicas montadas para tal fim. ${ }^{2}$ Os exames visavam dar mais garantias aos patrões de que seus filhos, caso não houvesse alternativa e precisassem ser nutridos por amas-de-leite, estariam mais protegidos contra uma série de doenças e 'germes' de moléstias, as quais, acreditavam os médicos, poderiam ser transmitidas às crianças (Castilho, 1882, p.14).

Não era comum, no Brasil, as crianças serem criadas nas casas das amas; elas costumavam permanecer nas casas dos pais naturais e, de certa forma, sob sua vigilância. Tal prática era em geral muito louvada pelos médicos brasileiros, que criticavam o hábito, ainda frequente naquele período na Europa e nos EUA, de os pais deixarem a criança ser 'criada' na casa da ama, geralmente no campo, mediante pagamento de quantia mensal. Acreditavam os médicos que essas crianças poderiam estar sujeitas a maus tratos, negligência e falta de carinho. $^{3}$

A formação do vínculo entre criança e família, sobretudo a mãe, também era considerada essencial por esses médicos, ainda que a mãe não amamentasse seu filho. Outro ponto criticado dizia respeito à possibilidade de a ama pegar mais de uma criança para criar em sua casa, além da sua própria, o que significava menor porção de leite para cada bebê e, visto que se esperava da ama que ela apresentasse o bebê sempre 'redondinho', a introdução precoce de alimentos para os quais o organismo infantil ainda não estava preparado (Castilho, 1882, p.17).

Para o senhor da escrava, seu aluguel como ama-de-leite podia render boa quantia mensal. Em alguns anúncios de venda ou aluguel, o proprietário fazia questão de frisar que a ama não tinha "vícios ou moléstias". Uma ama com 'bons costumes' - ou 'obediente' -, que fosse ainda 'carinhosa e fiel', era garantia de que o bebê estaria em boas mãos. Às vezes ressaltava-se o fato de que ela havia parido recentemente, ou seja, que o leite era novo. Outras vezes enfatizava-se ser o leite 'de primeira cria', o que podia significar que a candidata a ama talvez fosse inexperiente no trato com bebês. Alguns médicos higienistas aconselhavam as mulheres a contratar amas com primeira cria, pois acreditavam que seu leite era melhor, mais puro; outros defendiam que o leite da mulher multípara era mais forte, mais abundante, além da vantagem de que, por já ter outros filhos, ela teria mais prática em lidar com o bebê. 
A ama podia ser oferecida "com ou sem a pequena cria negra". Sorte tiveram as que amamentaram ao mesmo tempo o seu próprio bebê e o do senhor; com certeza, o trabalho excessivo e cansativo era compensado pelo fato de não se verem afastadas de seus filhos. Os senhores, entretanto, raramente concordavam em deixar o filho natural da ama ser criado junto ao seu bebê, mamando nos mesmos seios. Mais rara ainda era a probabilidade de que fosse levado em consideração o amor da ama pelo próprio filho. Quando havia assentimento, tratava-se, em geral, de tentativa de não 'estragar' o leite da nutriz - já que a escrava podia transmitir ao bebê do senhor, pelo leite, sentimentos de 'contrariedade' -, ou de evitar que a esse bebê se infligissem maus tratos. Por outro lado, a garantia da amamentação ao bebê negro aumentava as chances de sobrevivência dele. ${ }^{4}$

Não só a muitos senhores, mas também aos médicos da época pouco ou nada interessava o destino das crianças nascidas escravas. Muitas delas eram abandonadas à sorte nas rodas dos asilos, como ressaltou o psicanalista Jurandir Freire Costa (1983, p.168). Em tese de 1874, afirmou o médico Francisco Moura (1874, p.26): “A ama escrava, quando é alugada, não leva em sua companhia o seu filho; ela é obrigada pelo seu senhor, a fim de dar um aluguel maior, a abandoná-lo, portanto ela vai contrariada e odeia a família que a aluga, e principalmente a inocente criança a quem ela vai fazer as vezes de mãe!".

Com relação aos 'abalos morais' que influiriam na qualidade do leite, o médico Celso Eugenio dos Reis (1882, p.12) observou:

As emoções morais influem sobre a secreção do leite ... . O medo, a cólera, o pesar e todas as perturbações violentas da inervação têm influência muito notável sobre a secreção leitosa e sobre as qualidades do leite. Elas podem suspender durante 12 ou 24 horas esta secreção, e o leite que for secretado depois pode perturbar, durante muitos dias, as digestões da criança e determinar vômitos, cólicas, diarréia, convulsões e até a morte.

Já o viajante suíço Charles Pradez, que esteve no Rio de Janeiro por volta de 1872, percebeu o drama em que as amas estavam envolvidas e escreveu, indignado:

Uma coluna do Jornal do Commercio se enche todos os dias de anúncios de aluguel de amasde-leite; para quem sabe do que se trata, cada linha representa um drama íntimo, a história do naufrágio de uma aflição santa ou indica uma cruel separação; cada anúncio significa lágrimas, luto e desespero! Apesar disso, o interesse pesa sobre essas coisas e outras, pois cada ama corresponde de 120 a 150 francos por mês. Tirar o filho de sua mãe! Não é atroz? Não é revoltante? Pois é: fala-se da emancipação diante de algumas pessoas mais ou menos interessadas em manter a ordem de coisas atual e elas responderão que se é utópico, visionário, que os operários europeus são muito mais infelizes que os negros etc. etc. (Pradez, 1872, citado em Leite, 2000, p.69).

As tristes histórias de separação das amas negras escravas e seus filhos naturais narravam casos de crianças vendidas em separado da mãe ${ }^{5}$; daquelas que ficavam na casa dos senhores, enquanto a mãe era vendida ou alugada (nesses casos, eram criadas pelas demais escravas da casa); das que eram mandadas para casas de amas (geralmente mulheres livres pobres, brancas ou negras), que criavam vários, enquanto as mães eram alugadas; das que eram abandonadas nas rodas dos asilos e lá morriam ou se criavam alimentando-se do leite de uma ama, contratada para amamentar até dez bebês 'enjeitados'; e das que morriam ao nascer. No artigo "Maternidade negada", Renato Pinto Venâncio (2002) sugere que, antes 
da lei de 28 de setembro de 1871, alguns dos bebês negros podem ter sido colocados nas rodas após suas mães escravas terem sido convencidas, pelos senhores, de que os bebês cresceriam livres. As mães, então, 'concordariam' com o abandono e seriam alugadas como amas-de-leite, mas teriam o consolo de que, caso seus filhos conseguissem sobreviver, viveriam como pessoas livres. Muitas dessas mães, na esperança de futura alforria para si mesmas - prêmio merecido pelo trabalho como ama-de-leite, executado com dedicação e desvelo -, alimentaram também a ideia de que, uma vez livres, poderiam reaver seus filhos.

Em finais do século XVIII e durante todo o seguinte, surgiram no Brasil numerosas críticas com relação ao convívio 'íntimo' da família branca, no interior dos lares, com os negros escravos. Como mencionado anteriormente, tais críticas se tornaram mais frequentes a partir da década de 1850 e vinham, a princípio, de médicos que condenavam o aleitamento pelas amas-de-leite, chamando-o depreciativamente de 'aleitamento mercenário'. A suspeita com relação às criadas domésticas em geral aumentara muito nessa época, devido sobretudo às epidemias de febre amarela e cólera - as criadas, tendo maior contato com a rua, poderiam ser portadoras de doenças e transmiti-las à família de seus patrões.

Com a chegada de número cada vez maior de estrangeiros e, ainda, no afã de 'europeizar' o país, de se 'civilizar' (o que incluía necessariamente a diminuição do número de pessoas negras ao redor da família), tais críticas foram-se intensificando: a presença dos escravos corromperia moral e fisicamente a família. E assim como as teses de médicos, boa parte dos tratados antiescravistas também tinha como tema central a influência maléfica da escravidão no seio da família branca.

Em suas teses, os doutores em medicina no Brasil do século XIX normalmente dividiam o aleitamento em quatro tipos: materno, artificial, mercenário e misto feminino. O aleitamento materno seria fruto do amor materno, "o impulso mais sublime e generoso que emana do instinto da reprodução, e existe em todo o coração bem formado", escreveu o higienista Celso Reis (1882, p.15), em concordância com os demais doutores. Os médicos liberavam da amamentação apenas as mães com algum problema físico, de saúde ou de nervos. A essas, até certa altura, aconselhavam procurar uma boa ama-de-leite, examinada e aprovada por médico, sendo a alimentação artificial a última opção, quando fosse impossível encontrar ama com todas as condições exigidas. ${ }^{6}$

$\mathrm{O}$ aleitamento artificial poderia ser mediato, ou indireto, e imediato, ou direto (Cerqueira, 1882, p.34). No mediato, o bebê tomava o leite de vaca, cabra, ovelha ou jumenta, em colher, copo ou mamadeira, diluído em água cuja quantidade era reduzida aos poucos. O cuidado com a conservação do leite era imprescindível, pois se não fosse logo consumido o calor fazia com que se estragasse rapidamente. A partir dos anos 1870 passou-se a oferecer aos bebês leite condensado diluído e também farinha láctea, essa última uma novidade importada naquele período. No aleitamento artificial imediato, ou direto, não havia risco de o leite estragar, pois o bebê mamava diretamente no animal. Nesse caso, os médicos aconselhavam dar preferência às cabras. Diziam eles que o leite das jumentas assemelha-se mais ao humano, no entanto seria mais difícil lidar com esses animais do que com as cabras, de temperamento mais dócil:

O animal ordinariamente empregado é a cabra, porque a forma e o volume de suas tetas, que a criança pode facilmente apreender, a abundância e as qualidades de seu leite, a facilidade 
com que ela procura amamentar a criança, a espécie de afeição que muitas vezes contrai este animal pela mesma, e enfim a sua docilidade explicam bastante a preferência que se lhe dá. Quem ignora que há muitos destes animais, que depois de habituados não podem ouvir o choro da criança que amamentam sem logo vir aleitar-lhe? Quem desconhece o modo por que às vezes este animal procura dar suas tetas à criança?

A escolha do animal deve merecer muita atenção da parte interessada.

Sendo o leite desses animais muito rico, não deverá ser empregado esse modo de aleitamento antes da criança ter atingido aos cinco meses, ou então procurar-se-á uma cabra nova que tenha parido recentemente (Reis, 1882, p.21).

As cabras multíparas deveriam ser preferidas às primíparas, cujo leite costuma ser menos abundante e cessar em prazo menor (Cerqueira, 1882, p.40). Os médicos aconselhavam ainda que o animal fosse bem alimentado, que não vivesse o tempo todo preso, não tivesse chifres e que, no início do processo da amamentação e até que se acostumasse à criança, fosse constantemente vigiado (Reis, 1882, p.22).

O terceiro tipo de aleitamento, chamado de mercenário, deveria acontecer quando não fosse possível o materno, "quer por impossibilidade, quer por má vontade das mães", frisou Celso Reis (1882, p.25). Demandava os trabalhos de escolha da ama por parte dos pais e de inspeção por parte do médico, que deveria ser chamado para examinar com rigor e atenção as condições de saúde da candidata. Segundo Nicolau Cerqueira (1882), a amade-leite tinha que ser bem 'estudada' (examinada pelo médico), pois era "um grande fator da mortalidade assustadora que entre nós destrói a infância" (p.32). Sua constituição física deveria ser forte ou pelo menos regular, pois daí resultaria "a vantagem, não só da possibilidade de ter a ama um leite abundante e de boa qualidade, como também de não ser necessário mudá-la" (Reis, 1882, p.26). A idade ideal da ama, por consenso médico, variava entre 18-20 anos e 30-35 anos. Pregavam ainda os doutores que, "entre duas amas, uma que tenha o filho vivo e outra que já o tenha perdido, a escolha deverá recair nesta última, contanto que se verifique que a morte não é consequência da má qualidade do leite ou de alguma moléstia, que possa transmitir" (p.26).

A idade do leite deveria aproximar-se da idade do bebê, e a ama, de preferência, não deveria estar menstruando, o que afetaria a composição do leite. Já "a cópula moderada não influi na constituição do leite", escreveu Nicolau Cerqueira (1882, p.31). Dentes, gengivas e hálito das amas também deveriam ser bem observados pelo médico, assim como olhos, gânglios linfáticos e órgãos genitais. Coração e pulmão também deveriam ser examinados, assim como cicatrizes antigas. Recomendava-se interrogar a ama sobre suas condições anteriores de saúde, para que mulheres "raquíticas, escrofulosas, sifilíticas ou tuberculosas" não fossem contratadas, pois "da sua escolha dependeria a vida de um ente, que teve a infelicidade de não ser amamentado por quem lhe deu o ser" (Reis, 1882, p.25-27). Os seios também seriam avaliados pelo médico, devendo-se dar preferência às que os tivessem de "tamanho regular, firmes e elásticos, não muito duros; o mamelão, que deve achar-se isento de qualquer fenda ou ulceração, deve ser de dimensões medianas" (Cerqueira, 1882, p.33). O leite da ama teria que verter com facilidade após pequena pressão sobre o bico do peito, e sua qualidade poderia ser testada coletando-se um pouco dele para exame. Outra forma de medir a qualidade e quantidade do leite seria pelo "meio infalível", citado na tese de Thomaz Eboli (1880, p.7): "Pesa-se a criança antes e depois da amamentação". 
Da ama exigia-se que tivesse bons costumes, gênio dócil, fosse bastante cuidadosa e também inteligente, pois com essas qualidades desempenharia melhor sua função, zelando pelo bem da criança e "descansando assim os pais" (Reis, 1882, p.28). A ama ideal teria também a fisionomia agradável e seria alegre, e assim saberia distrair a criança e incentivá-la a procurar brincadeiras (p.28). Não deveria levar vida sedentária, o que diminuiria a quantidade e a qualidade do leite, e a alimentação a ela dispensada deveria ser controlada: "Devem-se dar à ama alimentos substanciais e de fácil digestão, como carne, legumes, caldos etc., e proibir-lhe as bebidas alcoólicas, fazendo uso com a maior parcimônia de ácidos e vegetais crus, assim como daqueles que têm a propriedade de diminuir a secreção láctea" (Eboli, 1880, p.9).

À ama caberia controlar os intervalos das mamadas, para que pudesse descansar; caso contrário, ao longo do tempo, com poucas horas de sono, o volume de seu leite poderia diminuir. Havia também o medo de que ela dormisse ao amamentar a criança, sufocandoa com o peso de seu corpo: "É conveniente que ela ocupe um quarto vasto, claro e bem ventilado; o leito deve ser estreito a fim de que ela não possa deitar a criança junto de si" (Reis, 1882, p.29). Tal preocupação não era desmedida, pois não raramente crianças muito pequenas morriam sufocadas sob o peso do corpo da ama (ou da mãe), que adormecera enquanto amamentava. Na verdade, esses casos costumavam ser mais frequentes em meio a pessoas que, sem condições de adquirir berço, acomodavam os bebês na própria cama. $\mathrm{Na}$ Europa e nos EUA, onde normalmente as crianças eram enviadas para a casa da ama no campo, os pais eram aconselhados a verificar se ali havia berço e, em caso negativo, a providenciá-lo. No Brasil, sendo mais usual as amas morarem com as famílias, o controle tornava-se mais fácil, apesar de se poder imaginar a 'tentação' da ama, exausta, na madrugada, de amamentar o bebê enquanto tirava um cochilo.

Recomendava-se ainda aos patrões exigir da ama um bom asseio, e ela deveria ser tratada, "mesmo quando escrava, com toda a atenção e agrado" (Reis, 1882, p.29). Alguns médicos defendiam que a mulher livre, fosse ela negra ou branca, não seria ideal como ama: interessada em manter seu ganho, esconderia dos patrões algum eventual problema de saúde ou diminuição no volume do leite, além da possibilidade de deixar seu posto sem nenhum aviso prévio, quando bem lhe aprouvesse. Já outros médicos criticavam os "hábitos de perversão moral e perversidade tão incutido nos escravos" e aconselhavam os pais a contratar amas livres, mulheres de princípios religiosos e morais, com alguma instrução e caráter meigo e carinhoso (Cerqueira, 1882, p.33).

A partir da década de 1850 aumentou o número de anúncios de senhoras brancas imigrantes (a maioria ainda portuguesa, naquele período) a se oferecerem como amas-deleite. Mas alguns médicos alertavam, em suas teses, que as mulheres a se prestar a tal serviço, 'nivelando-se' às escravas, teriam ambição desmedida e portanto deviam ser evitadas (Reis, 1882, p.32). Acreditava-se também que pelo leite seriam transmitidas à criança as 'qualidades culturais' da nutriz', daí as críticas às amas negras envolverem ojeriza racial contra os negros, acusando-se seu leite de transmitir, aos bebês brancos, características de inteligência, cultura e hábitos dos negros.

Sobre as doenças físicas, os médicos costumavam alegar que as amas poderiam transmitir, além das já citadas febre amarela e cólera, varíola, tuberculose, sífilis, escarlatina, malária, 
escrófulas, vermes, sarnas, parasitas de cabelo e até mesmo lepra. ${ }^{8}$ As doenças morais, por sua vez, estariam presentes no leite sob a forma de 'germes', que conteriam disposições hereditárias da escrava e se desenvolveriam mais tarde nos pequenos entes, a exemplo da suposta predisposição das escravas para a promiscuidade. O médico Thomas José Costa (1849) enfatizava:

A primeira infância é a idade da imitação, são bebidas com o leite, para assim dizer, as boas e más idéias; e os hábitos que se adquirem então são tanto mais difíceis de destruir-se para o futuro, quanto mais profundas são suas raízes. O que é natural dificilmente se pode reformar, e com muita razão se diz, que, se os homens têm qualidades, ou vícios, é sua ama de leite quem primeiro deve ser louvada, ou censurada, porque ela foi sua primeira instituidora.

Abstraindo-se o preconceito, algumas doenças de fato representavam grande perigo, porém a ameaça pairava igualmente sobre o bebê e a ama. Com relação à sífilis, por exemplo, que ocorria em qualquer camada social, da mesma forma que uma ama contaminada poderia transmitir a doença ao recém-nascido, este poderia já ter sido infectado pela própria mãe (a sífilis congênita) e passar a doença para sua nutriz. O risco era grande para a ama sadia, posto que os sintomas da sífilis congênita podem levar de seis a oito semanas para aparecer no bebê recém-nascido. Nesses casos, se os pais da criança (portadores da moléstia) não alertassem o médico sobre a doença, ou não fossem conhecidos dele (que, assim, saberia de sua doença), o profissional de saúde poderia atestar falsamente a saúde do bebê. ${ }^{9}$

Incompetência para lidar com as crianças também era questão frequentemente abordada. Além do risco de sufocar o bebê ao amamentá-lo em estado de sonolência, as amas eram acusadas de apertar excessivamente as vestes dos pequenos; de não dar importância (ou não alertar os pais) aos primeiros sinais de alguma moléstia, podendo assim agravar o quadro clínico do bebê; de introduzir precocemente, no cardápio dos bebês, alimentos inadequados, mesmo quando disso proibidas pelos pais da criança ou por seu médico; do uso de ervas, “bebidas espirituosas", segundo o médico José D'Araujo (1844, p.13), para "aquietar os bebês, diminuir seu choro e fazê-los dormir". Algumas amas, alegavam os médicos, provocavam hérnias nas crianças, de tanto que as deixavam a chorar, ou inflamações e escoriações, por deixarem-nas muito tempo com as fraldas sujas. Havia as que sacudiam violentamente as crianças, causando com isso "fraqueza moral, ou nervosa, incurável". Outras deixavam cair os bebês causando fraturas que os tornavam "defeituosos para sempre! E se não, que o digam esses indivíduos raquíticos e aleijados que encontramos todos os dias n'esta Côrte", exagerou José Augusto D'Araujo (1844, p.43). "Entretanto - escreveu anos depois Luiz Corrêa d'Azevedo (1873, p.67) - excepcionalmente encontram-se algumas escravas dotadas de boa índole, que, tratadas com solicitude e carinho, sendo sadias, consagrando estima às crianças e alimentando-as a seu bel-prazer, criam-nas perfeitamente".

As amas livres ou forras (brancas ou negras), porque vendiam seu leite de livre vontade, costumavam ser vistas com bastante desconfiança e acusadas de tentar enganar os médicos, escondendo doenças ou o fato de seu leite ser ralo e fraco. Alguns as condenavam, denominando-as 'mercenárias', por deixarem de lado seus próprios bebês ainda bem pequenos para obter a convidativa renda da venda do próprio leite. Poucos, porém, conseguiram perceber o sacrifício de mulheres pobres que se empregavam como amas. Muitas só procuravam esse serviço após amamentar durante meses seus próprios filhos, 
garantindo-lhes, assim, melhores oportunidades de sobrevivência. Apenas as mais necessitadas (desesperadas mesmo) procuravam trabalho como amas imediatamente após o nascimento de seus bebês. Fato é que, para garantir a sobrevivência dos filhos dos mais abastados, filhos de pessoas menos favorecidas morriam.

Os médicos higienistas 'ameaçavam' as mães que não amamentavam os próprios filhos com inflamações nos seios e em outros órgãos, devidas a líquidos que, no estado "de prenhes", se acumulavam no útero e seriam depois eliminados pela amamentação (Bretas, 1838, p.9). Mencionavam também a perda do amor do filho, que só teria carinho para aquela que o amamentara (Leitão, 1840, p.12-13) e assim incrementavam a campanha em favor da 'mãe higiênica'. Além das teses já citadas, foram publicados manuais, tratados e capítulos de teses voltados para as 'novas mães', orientando quanto a trato dos filhos, alimentação, higiene, vestimentas, exercícios, brincadeiras, educação, relação entre pais e filhos, entre outros temas. O médico Augusto José Pereira das Neves, em suas memórias, assim referiu-se à esposa que, entre 1864 e 1884, teve dez filhos e (sendo mulher de médico) fez questão de todos amamentar: "Todos estes filhos foram amamentados por Joanna, o que muito a debilitou, nunca engordando e ficando sempre de saúde fraca, mas ela fez questão de criar seus filhos ... . Deus ampare e proteja a esses meus filhos e a sua boa e dedicada mãe" (Neves, s.d., fl.17, citado em Priore, 1999, p.160). Joanna teve dez filhos em vinte anos. A amamentação não a impediu de continuar a procriar, mas lhe impôs o ritmo de só conceber a cada dois anos. De fato, a prática servia, para muitos casais, como método anticoncepcional natural, que ajudava a manter em média um intervalo de dois anos entre as gestações.

Retomando os diferentes tipos de aleitamento, classificados pelos doutores em medicina do período, o quarto tipo era aquele em que a mãe, por fraqueza física ou por considerar que tinha pouco leite ou leite 'fraco', mas não querendo privar-se de participar do ato de criar o bebê, dividia o aleitamento com uma ama. Chamado de misto feminino, esse tipo foi citado, entre outros autores, por João Baptista M. da Silva em sua tese (Silva, 1884, p.51-52).

Além do acesso direto dos médicos a muitas famílias (principalmente nos centros urbanos), outra forma de pressionar e tentar mudar as práticas de amamentação no Brasil foi a publicação de textos que exploravam histórias estimulantes de culpa e medo nas mães que não amamentavam seus filhos. Um dos periódicos que os veicularam foi a revista $A$ Mãi de Familia, publicada quinzenalmente na cidade do Rio de Janeiro entre 1879 e 1888 . O redator principal da revista era o doutor Carlos Costa, "especialista em moléstias das crianças" e responsável pela seção Palestra do Médico, na qual exaltava os benefícios do leite materno, atacava o uso de amas-de-leite, ressaltava os perigos que disso podiam advir e repetia os argumentos de seus colegas. A revista, que contava com a colaboração eventual de outros profissionais da medicina, orientava quanto ao exame médico da ama, caso seu emprego fosse inevitável; sobre o trato com o leite de animal, seu preparo e conservação, bem como a limpeza dos acessórios; e dava dicas de reconhecimento e tratamento de doenças infantis, de como lidar com as crianças, sua higiene, suas brincadeiras, seus passeios, sua educação, seu relacionamento com os familiares, entre outros temas.

Em julho de 1882 o doutor P. Blanche publicou, em A Mãi de Familia, a história da jovem mãe que queria amamentar seu filhinho recém-nascido, ainda que estivesse sendo pressionada a arranjar uma ama por sua própria mãe, que temia pela saúde da moça. 
Durante a consulta, o médico procurado conseguiu convencer a família de que a amamentação materna era melhor para a mãe e para o bebê. Orientou ainda a jovem sobre o trabalho que ela teria pela frente, prometeu acompanhar pessoalmente o desenvolvimento do bebê e, no final, exclamou: "Preza aos céus que todas as mães se comportassem como vós. Muitos inocentes seriam salvos!".

A historiadora americana Sandra Graham (1992) ressalta que o debate público sobre amamentação materna, com fôlego crescente a partir de meados do século XIX, não só levantara (mais) suspeitas sobre a ama-de-leite como figura ameaçadora, possível transmissora de doenças físicas e morais, como também começou a modificar a autoimagem das mulheres como mães. Graham argumenta que nas teses anteriores a essa época os médicos eram mais tolerantes com as mulheres que não amamentavam seus filhos (p.144). Periódicos como A Mãi de Familia vinham cumprir a missão de alcançar o âmbito familiar e influenciar, com suas histórias, as senhoras para que exercitassem seu papel materno, não importando o sacrifício necessário para tal. ${ }^{10}$ Culpa e medo foram explorados na tentativa de criar a 'nova mãe', a 'mãe higiênica', exaltada pelos médicos do período. Fator importante foi a intenção de desenvolver maior afeto das mães por seus filhos pequenos, o que, acreditava-se, garantiria a eles melhores condições de sobreviver à infância, visto que as 'novas mães' se tornariam aliadas dos médicos responsáveis pela saúde das crianças. Por muito tempo, entretanto, e para muitas famílias de posses, a escolha entre amamentar ou não ultrapassava o domínio exclusivo da mulher; tratava-se de decisão do casal e, às vezes, até do núcleo familiar mais abrangente. ${ }^{11} \mathrm{~A}$ ocupação da mãe com a amamentação, entretanto, além de proteger a vida dos filhos, tinha outro papel social: ater a mulher a um universo disciplinar; controlar o comportamento social feminino.

\section{Haveria também 'afeto'?}

Como mencionei, o recurso prosseguiu por algum tempo, apesar das constantes críticas e da exaltação aos possíveis 'perigos' que dele advinham. Na segunda metade do século XIX, muitas amas-de-leite (ou já amas-secas) foram levadas pelos patrões aos estúdios fotográficos mais modernos das cidades e retratadas, bem-vestidas e adornadas, com a criança branca ao colo ou a seu lado, sugerindo uma relação positiva, de harmonia e afeto (Figuras $1 \mathrm{a}$ 4). Cabe aqui uma breve reflexão a respeito desse afeto, o afeto dos senhores pelas amas de seus filhos, destas pelos senhores e pelas crianças que amamentavam, e o afeto dessas crianças por suas amas. Ele pode ajudar a compreender os motivos da produção de fotos e sua permanência nos álbuns das famílias brancas.

A questão certamente envolve o paternalismo, entendido como uma rede de deveres e direitos recíprocos: os senhores ofereciam proteção (sustento, comida, roupa, teto e trato de doenças), respeito e justiça (mesmo quando castigavam) e, em troca, exigiam obediência, trabalho (dedicação) e fidelidade (gratidão) (Genovese, 1988; Graham, 1992; Chalhoub, 2003). Posto que a ama, por sua vez, também devia proteger o bebê, formava-se um círculo de trocas e expectativas, bem abordado, aliás, por Sandra Graham (1992, p.61):

As criadas pessoais - camareiras e amas-de-leite - podiam aspirar a ser recompensadas com afeição ou confiança. No curso de seu trabalho, essas criadas atravessavam com freqüência os 
Sandra Sofia Machado Koutsoukos

espaços da casa exclusivos dos membros da família e mantinham com estes um contato diário. Por meio da infinidade de pequenas atenções que prestavam aos patrões, podiam testemunhar de perto o lazer e a riqueza, que pertenciam a uma classe da qual elas, por serem pobres e serviçais, permaneceriam para sempre e de todo afastadas. Ainda assim, elas sensatamente se identificavam com as famílias às quais pertenciam. Ser uma mucama ou ama trazia recompensas tangíveis - entendidas como tais por ambos os lados - em retribuição por um serviço apreciado: podiam receber um atavio ou ornamento que significasse um status especial, como, por exemplo, um lenço de seda para atar o cabelo ou um par de chinelas; uma excursão, ou, às vezes, até uma longa viagem ...

Quem sabe, talvez, algumas amas tenham ganhado um retrato seu, tirado em estúdio de fotografia, com as crianças que amamentavam ou haviam amamentado, como gesto de atenção, carinho ou saudade? Graham (1992, p.61) acrescenta, ao se referir à figura da velha ama de finais do século XIX:

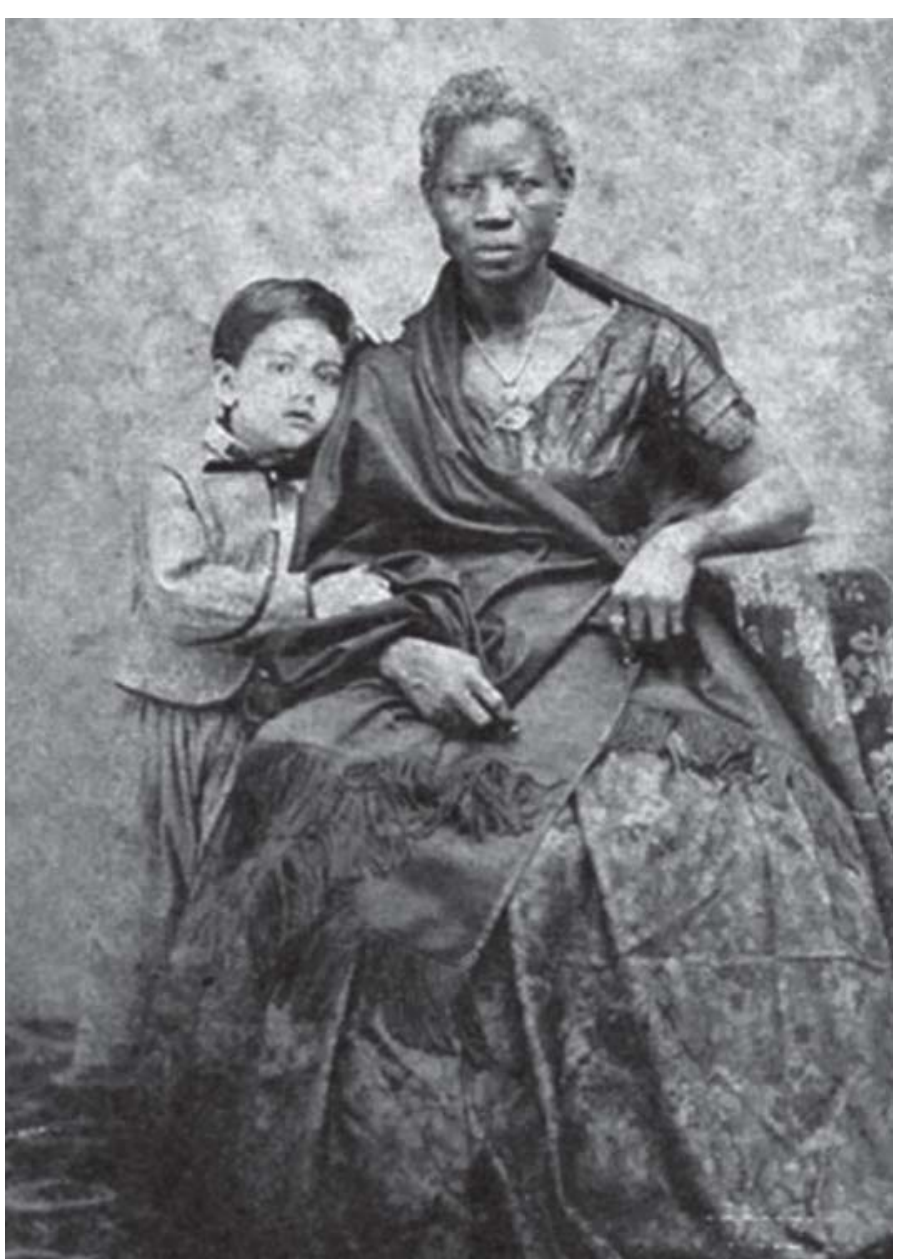

Figura 1: Foto de Augusto Gomes Leal e da ama-de-leite Mônica, do estúdio de João Ferreira Villela, Recife, c.1860. Cartão-de-visita, 6,5 x 10cm. (Coleção Francisco Rodrigues, CFR 1795,

Fundação Joaquim Nabuco de Pesquisas Sociais)

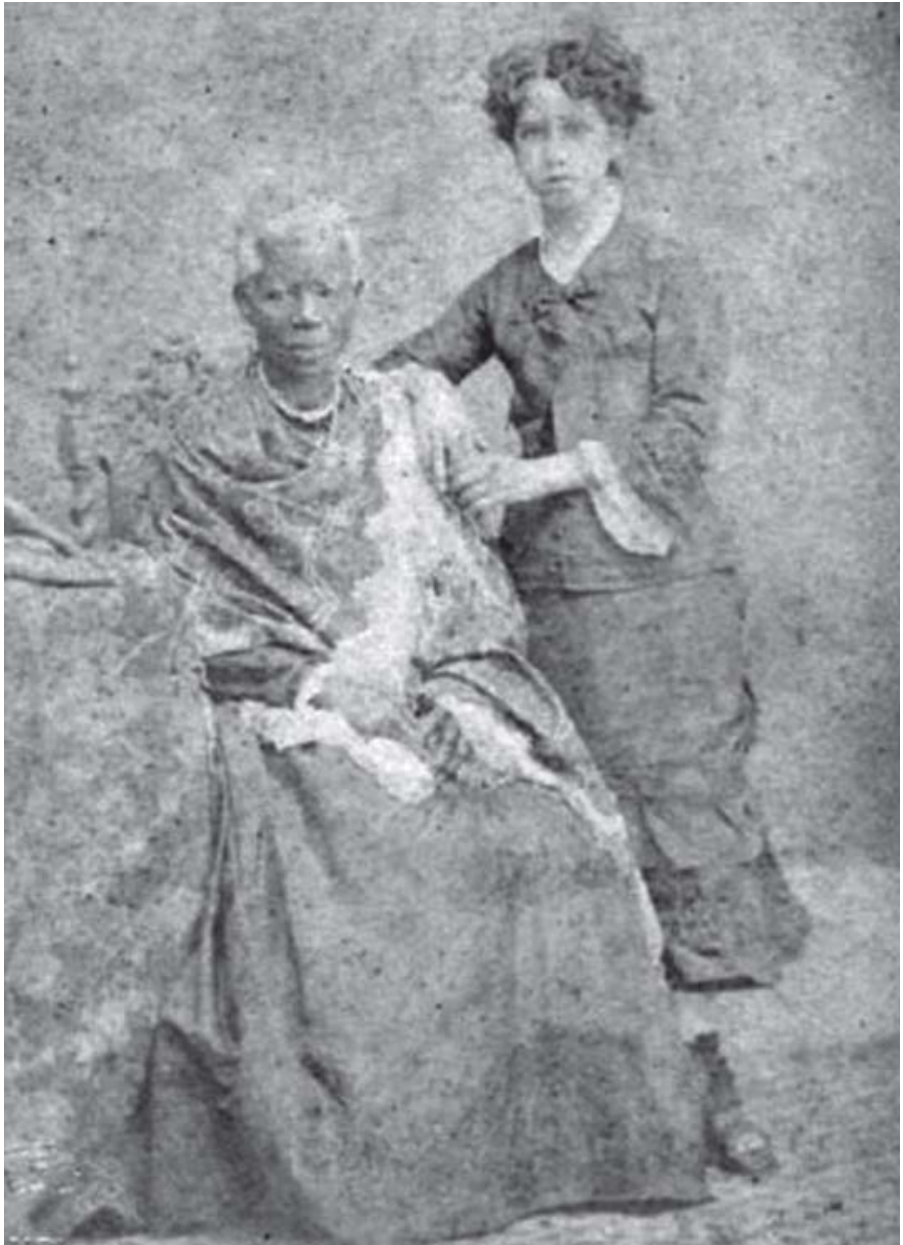

Figura 2: Foto de Isabel Adelaide Leal e da ama-de-leite Mônica, do estúdio de Alberto Henschel, Recife, [1877-1882]. Cartão-de-visita, $6,5 \times 10 \mathrm{~cm}$.

(Coleção Francisco Rodrigues, CFR 2139,

Fundação Joaquim Nabuco de Pesquisas Sociais) 
Conforme os escravos iam diminuindo em número e não eram substituídos por outros nos lares do Rio de Janeiro, as criadas pessoais que serviam por toda a vida e estavam ligadas à família do patrão por fortes laços de lealdade e privilégio foram gradualmente desaparecendo. No entanto, as criadas favoritas continuaram a existir, de forma ligeiramente diferente. A mulher livre, a ama-seca das diversas crianças de uma família, podia manter um lugar na casa mesmo muito depois que as crianças tivessem crescido, como uma velha e respeitada figura que merecia afeição e cuidados.

Não teria sido um fardo, para alguns, a velha ama, do qual eles não tinham coragem ou meios de se livrar? Afinal, anos após o dever cumprido (algumas vezes com mais de uma criança da família), já estando velha, adoentada, inútil para qualquer tipo de serviço, não poderia ser a ama considerada um fardo, ao qual a família agora devia proteção, cuidados e 'até' afeto?

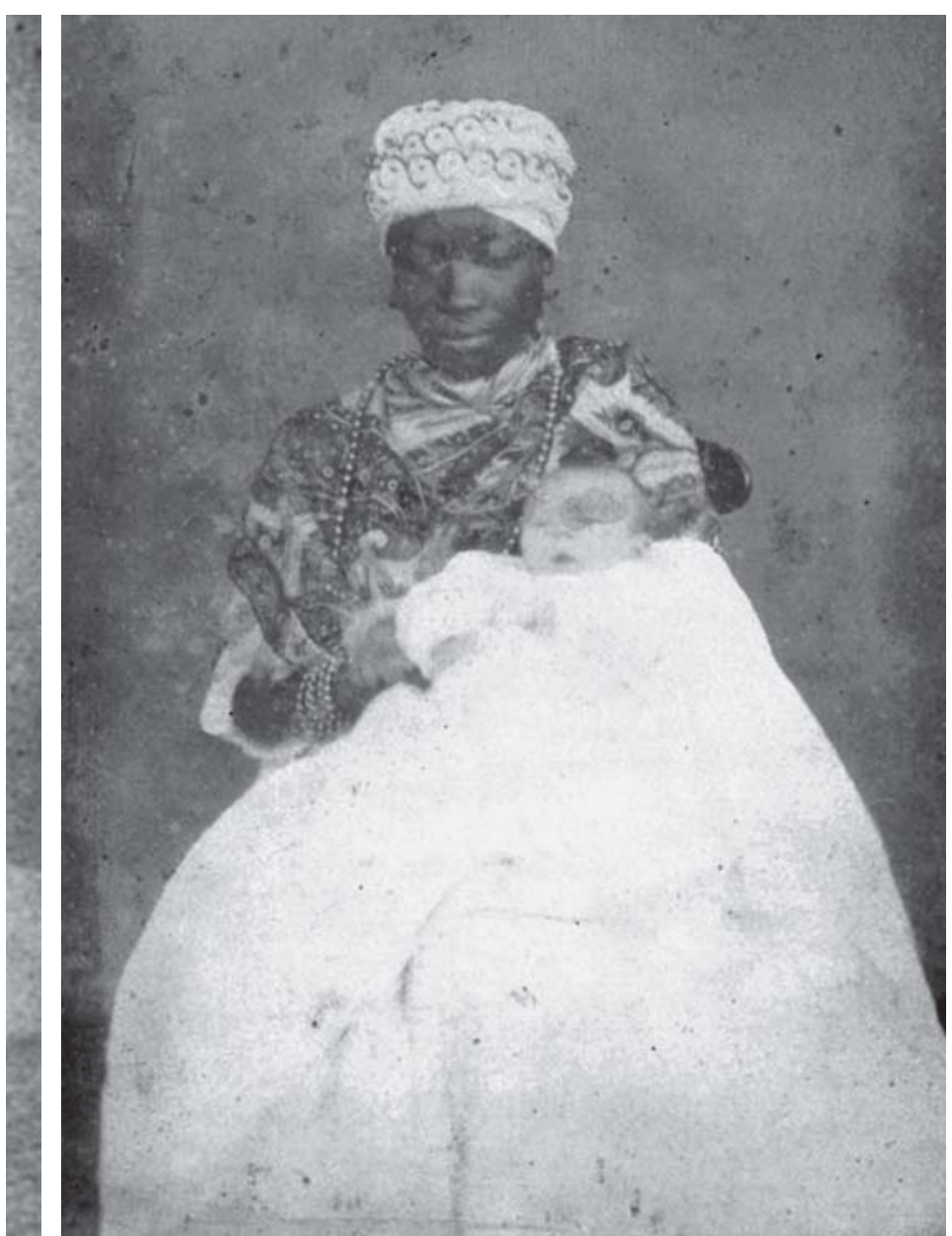

Figura 3: Foto de Maria Rita Meireles da Costa Pinto com a ama-de-leite Benvinda, do estúdio de Antonio da Silva Lopes Cardozo, Bahia, c. 1881. Carte-cabinet, 11 x 16,5cm. (Arquivo Nacional, 02/FOT/76)

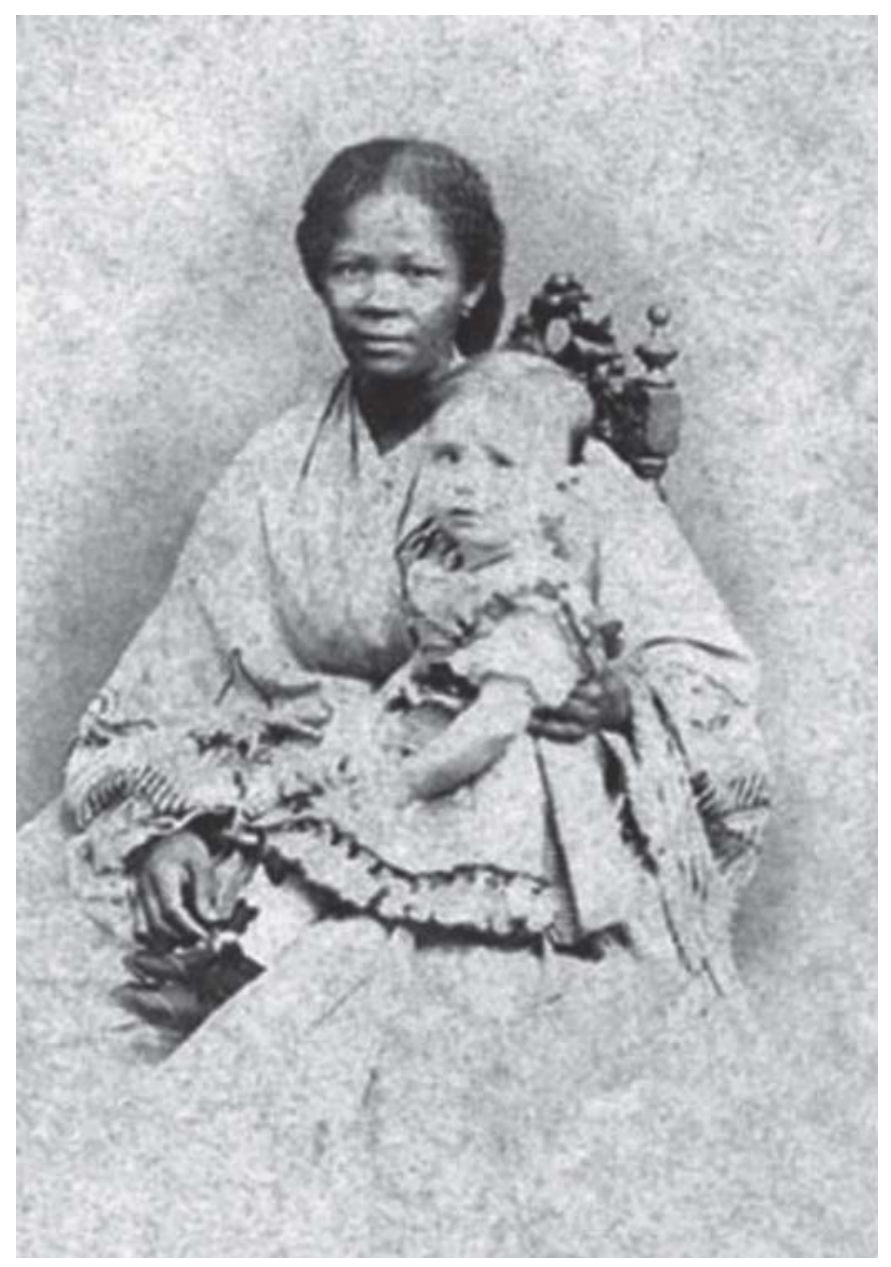

Figura 4: Foto de José Eugênio Moreira Alves e amade-leite, do estúdio de Alberto Henschel, Recife, [1866-1877]. Cartão-de-visita, 6,5 x 10cm.) (Coleção Francisco Rodrigues, CFR 551,

Fundação Joaquim Nabuco de Pesquisas Sociais) 
Vejamos as Figuras 1 e 2. A primeira retrata a ama Mônica junto ao menino que criara. Pela idade da criança, mesmo que a tenha amamentado, Mônica era naquele momento apenas sua ama-seca; na lembrança da criança, seria sua 'mãe-preta'. Os pais do menino provavelmente estiveram presentes no estúdio, participando da organização da cena, junto ao fotógrafo (Koutsoukos, 2007c). Ricamente vestida e ataviada, Mônica foi representada como uma madonna negra, pela sua figura centralizada na foto, por sua vestimenta, pela posição de braços e mãos, pelo modo como o menino se aconchega e se apoia em seu ombro direito. Mônica foi postada como as madonnas representadas durante séculos em pinturas no Ocidente (Figura 5), mas é uma madonna negra com uma criança branca junto a si, que não é fruto de seu ventre, mas seu filho de leite. Esse arranjo de cena era comum nas fotos (e pinturas) de mães com filhos, em que também tentava-se evidenciar ideias de intimidade, harmonia e afeto (Figura 6).

Os adornos escolhidos para Mônica procuravam 'distanciá-la' da situação de simples criada. O luxo com que é mostrada expõe a riqueza da casa a que pertence, assim como sua posição algo privilegiada perante outros escravos da família (Leite, 2000). Entretanto isso pode esconder, muitas vezes, a história triste - não contada, mas pressuposta - da separação de uma escrava de seu filho natural. A referência à ama-de-leite conduz à ideia da existência de duas crianças: o bebê senhorial, por ela criado, e o bebê negro, fruto de seu ventre, do qual pouco ficamos sabendo. ${ }^{12}$

Inocente nesse arranjo, o menino (em trajes que reproduzem o figurino adulto) recosta a cabeça e as mãozinhas em sua mãe-preta. Ela é 'coisa' sua, por afeto - e mais tarde, talvez, continuasse a ser por herança. ${ }^{13}$ É possível que houvesse também, por parte da ama, afeto genuíno pela criança que amamentara. O que chama a atenção, na foto, é que, apesar de ter sido adornada com rica parafernália e talvez não ter ido ao estúdio por livre vontade, não se intimidou perante o equipamento e conseguiu dar sua contribuição pessoal: um olhar que encara a máquina, como a querer contar-nos sua história, e o xale vestido como um pano-da-costa, que cobre o ombro direito, passa sob a axila esquerda e vem cruzar na frente. ${ }^{14} \mathrm{O}$ luxo não consegue mascarar a condição humilhante de escrava e ela participa na construção de sua própria imagem. O retrato de Mônica é seu rosto, mas é também seu ombro quase desnudo, pelo movimento dado ao xale, e suas mãos grossas e encolhidas, de veias altas - mãos de quem trabalhou muito, adornadas por jóias que possivelmente não lhe pertenciam, mãos de quem não sabia bem como se posicionar para a foto. Seus cabelos brancos revelam uma gravidez algo tardia; seu último filho natural teria provavelmente, na época, a idade do menino da foto. Posando tão bem vestida, certamente não era escrava alugada, mas sim pertencia à família. Posando tão bem vestida, estaria ela calçada ou descalça? Não se vêem seus pés na foto, mas creio que estivesse calçada. Conseguira ela sua alforria, fruto do reconhecimento de tamanha dedicação? O fotógrafo não pediu que Mônica desviasse aquele olhar ou se portasse de outra maneira porque não quis (talvez não tenha sequer reparado), e assim conseguiu fazer uma das melhores fotos de ama que temos no Brasil, uma imagem que, sozinha, pode dizer tanto de uma parte de nossa história. ${ }^{15}$

A Figura 2 é uma foto da mesma Mônica, já com os cabelos completamente embranquecidos. Foi tirada entre 1877 e 1882, e a ama mostra a mesma expressividade no rosto e 
no olhar, acrescida de um meio sorriso. Novamente está bem-vestida, com roupas de corte ocidentalizado, e dessa vez mantém o xale de modo diferente, a cobrir os dois ombros. Em pé, a seu lado, está uma adolescente da mesma família à que pertencia o menino da foto tirada anos antes, o que torna possível ter sido Mônica ama-de-leite ou ama-seca de mais de uma criança da família. Talvez tenha vivido com a família até sua velhice. Como observou Sandra Graham (1992, p.61), a ama que aleitara diversas crianças de uma família e conquistara o direito de manter um lugar na casa, mesmo depois de as crianças terem crescido, era vista "como uma velha e respeitada figura que merecia afeição e cuidados". Tudo indica que temos uma delas aqui. A idosa Mônica, após anos de dedicação, e mesmo que tenha conseguido sua carta de alforria, pode ter continuado a viver com a família,

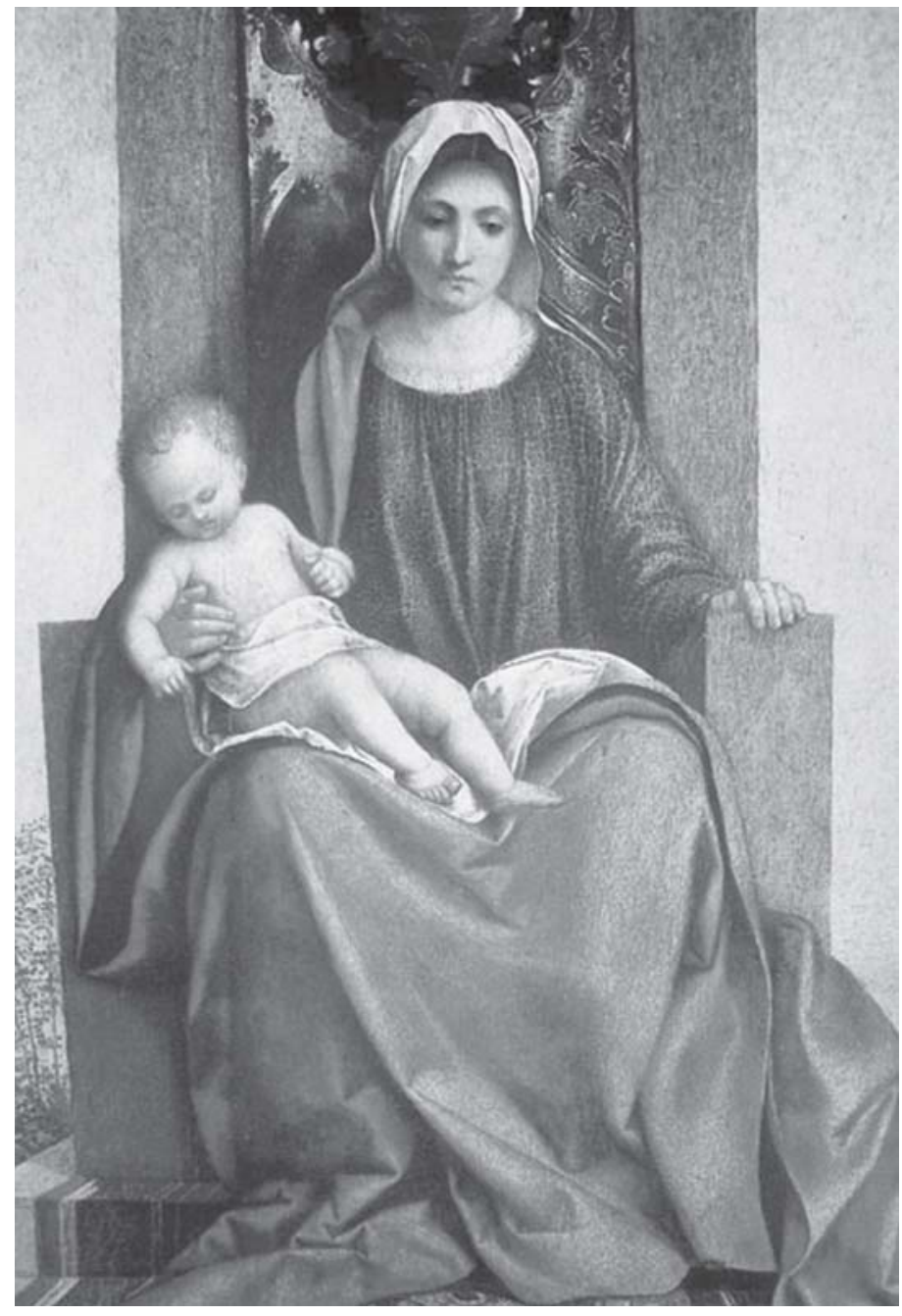

Figura 5: Detalhe de "Nossa senhora ao trono com o Menino e os Santos Liberal e Francisco", de Giorgione, da virada do século XV para o XVI. $200 \times 152 \mathrm{~cm}$. O original encontra-se na Igreja de São Liberal, Castelfranco. Reproduzida de Bardi, s.d.

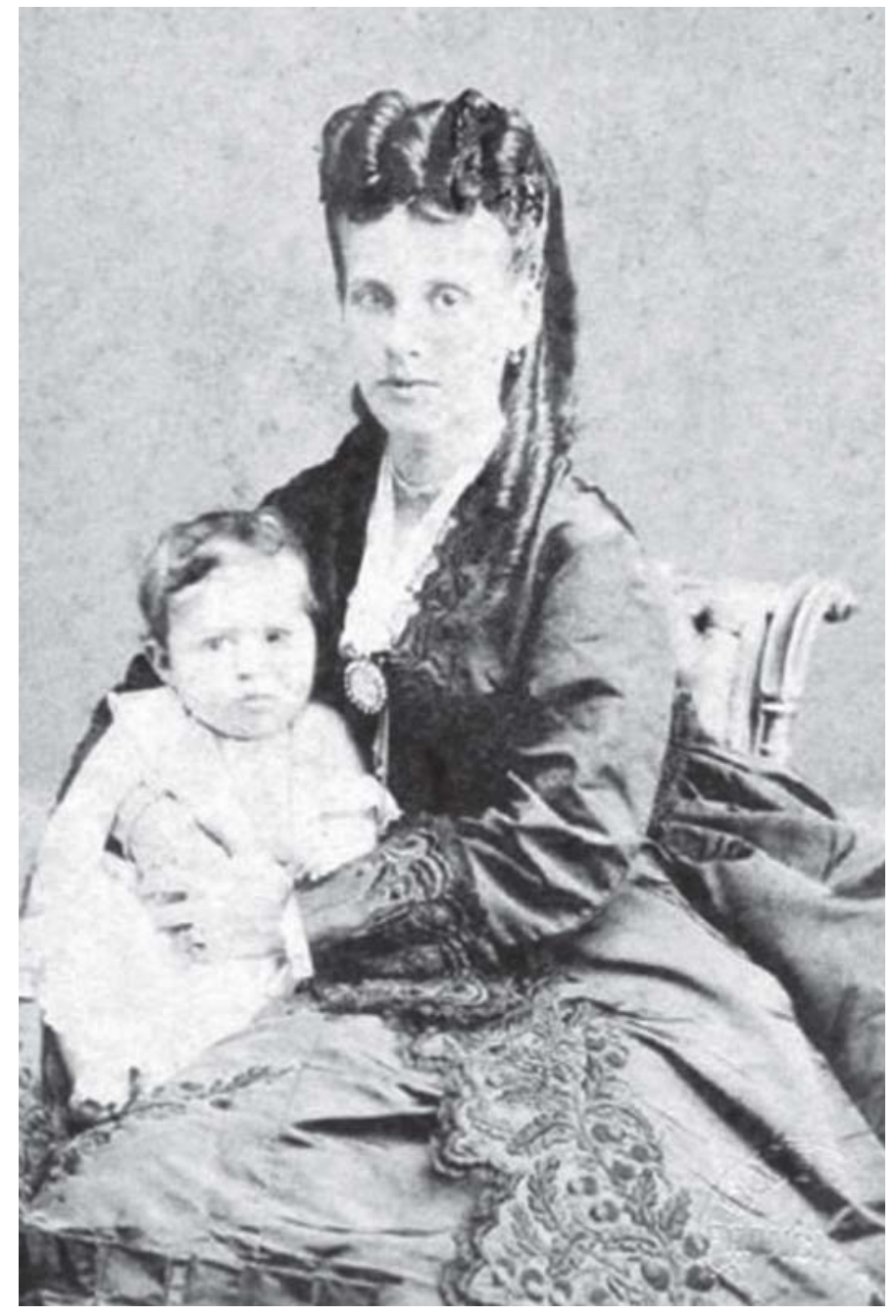

Figura 6: Foto de mãe com criança, do estúdio de fotógrafo Alberto Henschel, Recife, [1866-1877]. Cartão-de-visita, $6,5 \times 10 \mathrm{~cm}$. (Coleção Francisco Rodrigues, CFR 2642, Fundação Joaquim Nabuco de Pesquisas Sociais; Recife) 
como figura querida que cumprira seu papel sem decepcionar os senhores, sem desobediências, sem ingratidões. Pode ter conseguido conquistar seu pequeno espaço no seio de 'sua' família branca e o direito a teto, roupas, comida e cuidados na velhice. Pelo duplo registro de sua figura, é bastante possível que isso tenha ocorrido com a ama Mônica.

Para instigar um pouco mais o leitor, a próxima história escolhida explora algumas contradições da complexa relação entre senhores e amas. Em Crônicas: histórias do Rio colonial, Nireu Oliveira Cavalcanti (2004, p.187-189) revela ter encontrado, no Arquivo Nacional do Rio de Janeiro, um processo cujos elementos transcreve sob o título "A amade-leite: a escravidão e suas contradições". A história transcorreu em 1803. Trata-se de um casal que, após o nascimento da primeira filha, alugou por 3.200 réis mensais uma ama-deleite escrava chamada Joaquina, de nação Mina. Joaquina mostrou-se dedicada à criança e o casal a manteve até o desmame. Quando nasceu a segunda filha, os pais tentaram alugar Joaquina novamente, mas sua proprietária recusou alegando que ela também era boa nos serviços domésticos. Após alguma negociação, a senhora aceitou vender a escrava por 102.400 réis. Porém, tendo talvez alguma estima pela moça, estabeleceu a "condição infalível" de que, passados três anos da data da venda, ficaria a "escrava forra e livre, sem mais obrigações de servir aos ditos senhores, só querendo". O acordo foi feito, visto que os novos senhores também gostavam da moça e da forma como ela se dedicava com carinho e agrado a suas filhas.

Passado algum tempo, ciente do fato de que ficaria livre após três anos de sua venda, Joaquina começou a mostrar-se "desobediente" e "petulante", respondendo mal a sua senhora. Certa feita, ficou possessa com uma resposta da ama e deu-lhe um murro. Reagindo à agressão, Joaquina avançou na senhora, deu-lhe dentadas, arranhões, empurrões e "proferiu muitas palavras ofensivas". A vizinhança precisou apartar a briga, e testemunhas declararam ter tirado de Joaquina o bebê de seis meses, a quem a escrava também mordeu. Um médico foi chamado para atestar os ferimentos sofridos pela mãe e pela criança.

Em virtude do ocorrido, os senhores não sabiam o que fazer com a escrava. Não queriam mandar prendê-la e ficar no prejuízo. Também não conseguiriam vendê-la pelo que haviam pago por ela, dada a cláusula contratual que lhe libertaria em pouco tempo. O casal resolveu, então, vingar-se de Joaquina contratando um advogado para tentar anular sua alforria condicional. A batalha jurídica deu-se entre o advogado dos novos senhores e o advogado contratado pela antiga proprietária de Joaquina (que, pelo visto, se manteve do lado da ex-escrava). No final da questão, tudo ficou como estava, pois se concluiu que a anulação só caberia se Joaquina tivesse agredido a antiga dona, que lhe condicionara a alforria. Derrotados, os senhores da escrava tiveram que decidir o que fazer com ela ou de que forma com ela conviver até que fosse liberta. ${ }^{16}$

Interessa ressaltar aqui o fato de Joaquina ter sido 'querida' enquanto durou sua dedicação. Aparentemente, ao perceber que, sendo ou não dedicada e fiel, sua liberdade estava garantida, ela mudou de atitude. Da mesma forma mudou a atitude dos senhores, a princípio tão agradecidos com os cuidados para com suas filhas, a ponto de concordarem com a liberdade da escrava após três anos de sua compra. Por certo concordaram com a cláusula por considerá-la merecida, mas diante da 'ingratidão' da ama, o 'afeto' deu lugar a sentimentos de decepção, raiva e vingança, que quiseram expressar restituindo para si o 
poder sobre a liberdade da escrava. Caso essa liberdade tivesse sido condicionada à qualidade dos serviços prestados como ama-de-leite, a história poderia ter sido outra - e, nesse caso, na lembrança da família talvez ficassem apenas os sentimentos de gratidão e apreço.

Enquanto foi grata, obediente e dedicada, Joaquina foi querida, protegida e recompensada. Alterado o equilíbrio da situação, no lugar do 'afeto' surgiram outros sentimentos, menos dignificantes. O historiador Sidney Chalhoub (2003, p.134-135) ressalta que o paternalismo dos senhores e as relações de dependência dos domésticos livres ou escravos provocavam, com frequência, situações de violência e humilhação. Os senhores podiam demonstrar a 'estima' pelos dependentes, mas sua situação de superioridade lhes impunha, às vezes, sofrimento e humilhação. Já os dependentes, livres ou escravos, eram-lhes até certo ponto 'agradecidos', mas se sabiam em situação de inferioridade social. Mesmo quando tratados com o respeito que mereciam, como pessoas 'da família', se tentassem demonstrar pensamentos e sentimentos contrários ou impróprios, do ponto de vista dos senhores, tornavam-se, desse mesmo ponto de vista, 'ingratos', 'insolentes', 'dissimulados' e 'atrevidos'.

A história de Joaquina vem-se juntar ao alarmismo direcionado às mães brancas no período. Nela, o 'afeto' dos patrões pelas amas ia até onde elas lhes suprissem as expectativas de dedicação e zelo pelos bebês e pelas famílias. Nela, semelhante a tantas outras, desfaz-se a ideia da ama maternal e protetora - ao menos, a partir do momento em que não mais interessou a Joaquina assim ser. Em casos como esse, tanto seria enorme risco ter uma ama quanto significaria imensa dor ser uma ama.

Também não é difícil imaginar o reverso da história: Joaquina era escrava servil, carinhosa e dedicada, mas, ainda que estivesse sendo bem tratada na casa da nova família, com a liberdade em vista tornou-se respondona e até revidou com mordidas o murro que recebeu da senhora. Exceções, é claro, houve. Não foram poucos os casos de escravas (e escravos) que se apegaram às famílias e com elas permaneceram por livre vontade, mesmo após a abolição, não apenas por necessidade de proteção (teto, roupa, comida, trato de doenças e velhice 'amparada'), mas por se sentirem bem na casa (ou na ex-senzala) dos senhores, ou pelo sentimento de que faziam parte das famílias brancas que tinham servido.

Da relação entre esses dois segmentos sociais, pode-se dizer que as amas retratadas em estúdios - que haviam, portanto, não só conquistado o 'direito' de aparecer nas fotografias, mas também o de terem suas fotos guardadas pelas famílias a que serviam - teriam conseguido superar ao menos algumas das suspeitas que as figuras das amas despertavam então, e se tornado, de alguma forma e até certa medida, bem-queridas. O quanto de manipulação e cálculo houve em cada caso, da parte de cada um dos envolvidos, assim como o quanto houve de afeto, recíproco ou não, ou mesmo de humilhação e dor, ou alegria, é impossível saber ao certo. Podemos, porém, intuir que houve boa dose de quase todos esses ingredientes.

Para encerrar a exploração do possível 'afeto' envolvendo as personagens desta investigação, vejamos algo da relação entre as amas e as crianças brancas que criavam. Em Recordações de infância de Carlota Schmidt no Ibicaba, a então pequena Carlota (com oito anos), quando em viagem de visita com o pai aos parentes dele na Alemanha, em 1884, comprou presentes para trazer de volta ao Brasil. A menina lembrou-se primeiro da mãe, dos avós e dos irmãos, depois dos "pretos amigos e amigas", que presentearia com broches. 
Para a escrava que fora sua ama-de-leite, o presente principal seria caprichado, incluindo um retrato da menina (possivelmente tirado durante a viagem): "para minha ama um medalhão prateado com corrente, com minha fotografia e muitas coisas mais" (citado em Heflinger Jr., Levy, Cantalice, 2005, p.35). Carlota demonstrou, no presente escolhido com capricho, seu afeto genuíno pela ama que, pouco tempo depois, também encontrou modo de demonstrar seu apreço pela menina, convidando-a para batizar uma filha sua. Quando, após a morte da mãe de Carlota no parto do nono filho, a menina, o pai e os irmãos partiram de vez para a Alemanha, a ama lhe prometeu que, mais tarde, enviaria sua filha, afilhada de Carlota, para a Alemanha, a fim de que a servisse como mucama. "Mas isso nunca aconteceu", escreveu Carlota (p.37). Quem sabe a ama e sua filha tenham tomado outro rumo após a abolição, já que a promessa fora feita no momento da partida da menina, em março de 1888 ?

Talvez o afeto da criança por sua ama seja o único não questionável. Na maioria das vezes, nos livros de memórias, a lembrança da ama é guardada com carinho, sobretudo se ela permaneceu junto à família após o desmame, por ser escrava ou ex-escrava da casa, ou agregada.

Ainda que houvesse gratidão e até boa dose de afeto, por parte dos senhores, pelas que foram consideradas 'boas amas', esses sentimentos talvez não fossem as únicas justificativas para a encomenda de retratos dessas mulheres. Diante da crescente condenação, por parte de doutores em medicina e alguns teóricos moralistas (especialmente nas últimas décadas do século XIX) do uso das amas, diante das ideias e ideais abolicionistas que se iam impondo - até culminar com o fim da escravatura em 1888 -, pode ter sido intenção daqueles senhores, ao encomendar tais composições, mostrar que, afinal, a servidão daquelas mulheres e seu uso naquela situação não eram de fato tão ruins quanto se tentava apregoar. Dessa tentativa de passar a ideia de harmonia e afeto talvez decorra a construção formal das fotos de amas, a remeter às fotos de mães com seus filhos, às imagens de madonnas, a exemplo de Mônica (Figura 1), Benvinda (Figura 3) e a ama da Figura 4. Assim talvez se explique a suposta valorização das amas, apresentadas tão bem vestidas, tratadas e queridas, aproximadas da câmera e postadas junto às crianças, como sujeito e assunto daqueles retratos (Koutsoukos, 2006). Teria sido essa uma forma de mostrar que havia um lado positivo na amamentação por amas e, consequentemente, uma tentativa de diminuir a própria culpa por colaborar para a manutenção de tal situação? Ou cabe supor que alguns daqueles senhores poderiam ter encomendado tais retratos para, mais tarde, mostrar à criança que, embora não tivesse sido amamentada pela mãe, ela tivera uma boa ama, como atestava a fotografia (Koutsoukos, 2005)?

Não podemos também deixar de lado o fato de que, para alguns, a foto de suas crianças com as amas negras podia simplesmente significar mais uma moda a ser copiada, em voga na segunda metade do século XIX (há exemplos de retratos semelhantes tirados nos EUA), ou que se trata de mais uma forma de autorrepresentação das famílias senhoriais, uma imagem que viria compor tão bem o leque temático do álbum da família. ${ }^{17}$

O motivo para a feitura do retrato da ama com o bebê pode não ter sido nenhum desses, mas sim a 'rede de afetos' (e reciprocidades) que envolveu muitas dessas relações - a vontade de ter registrada aquela figura tão querida, para que o 'pequeno' pudesse ter, 
depois de crescido, a lembrança guardada com carinho, tal como faria a ama, de posse de uma cópia da foto.

Por fim, apesar de a situação de uma ama escrava ser de posse (por parte dos senhores) e, talvez até, de violência (nos casos em que a ama era separada de seu filho natural), para muitas a 'proteção' de uma família que as vestia, alimentava e cuidava pode ter sido considerada uma boa vantagem, dada a condição de insegurança (financeira e social) que a liberdade podia significar. Sandra Graham (1992, p.16) bem abordou esse assunto, esclarecendo que alguns empregados domésticos encontravam, na rua, relações instáveis e inseguras, ao passo que a casa do senhor (patrão) era o lugar da estabilidade e segurança. No caso das amas livres ou libertas, deve ter havido também aquelas que se interessaram pelo status advindo do trabalho como ama de uma família de posses, enquanto seu bebê dividia o leite com outra criança, ou era alimentado de forma alternativa. Além disso, o trabalho lhe renderia haveres que, muitas vezes, garantia a sobrevivência de várias pessoas ou ajudaria a colocar em prática um projeto de vida, tal como comprar a liberdade de um parente, uma casinha, um pedaço de terra, ou economizar para tempos mais difíceis.

Rima Apple (1987, p.97) comenta que a diminuição gradual do emprego de amas-deleite, mais sentida nos EUA entre 1890 e 1950, ocorreu por vários fatores: ao avanço na alimentação artificial (novas fórmulas, especialização do sistema de pasteurização do leite de vaca, novos formatos de bicos e mamadeiras etc.); ao fato de a alimentação artificial ser mais barata e menos complicada do que a contratação de uma ama; e à noção de 'nova mãe', à ideologia da 'maternidade científica', voltada para a saúde e higiene da criança e que requeria seu trato pela mãe, além de acompanhamento e orientação dos profissionais de saúde especializados em pediatria e puericultura. No Brasil, é difícil imaginar que um hábito tão arraigado tenha se alterado da noite para o dia. Ao que parece, o costume de amamentar os próprios filhos fez adeptos mais rapidamente nos maiores centros urbanos (como Rio de Janeiro, São Paulo, Recife e Salvador) do que naqueles mais afastados das influências europeias e norte-americanas, como fazendas e engenhos do interior.

\section{NOTAS}

${ }^{1}$ Manuais como o de I.B.A. Imbert, Manual do fazendeiro ou tratado doméstico sobre as enfermidades, de 1839, orientavam na compra de uma peça escrava (cf. Schwarcz, 1996, p.14).

${ }^{2}$ Um exemplo de dessas iniciativas são as Posturas municipaes... (1886).

${ }^{3} \mathrm{O}$ costume em várias sociedades de então, de mandar os bebês para a casa de uma ama no campo, deviase ao fato de ser este considerado mais saudável do que as cidades, acrescentando-se a vantagem de que, livre da amamentação, a mulher poderia logo engravidar novamente - uma vez que a maioria das crianças morria ainda na infância, era 'aconselhável' que o casal tivesse muitos filhos. Outro motivo decorria, muitas vezes, de a família (o pai, principalmente) não querer o inconveniente de tê-los em casa, com uma ama estranha a atrapalhar a rotina. Também eram raras as mulheres que manifestavam desejo de amamentar seus bebês, sendo muitas vezes dissuadidas ou até impedidas pela família. Alguns bebês eram constantemente visitados pelos pais, ou arranjava-se para que fossem com a ama ver os pais. Outros ficavam na casa da ama no campo sem nunca receber visita; os pais eram informados periodicamente sobre seu estado de saúde, quando também recebiam uma lista de roupas e apetrechos de que as crianças necessitavam. Várias morriam durante a estada no campo e eram enterradas ali mesmo, sem a presença dos pais. Os que sobreviviam e retornavam à casa paterna, com cerca de dois anos de idade, tinham de se adaptar à rotina de uma família que, afinal, lhes era estranha (Fildes, 1988, p.82-83). 
${ }^{4} \mathrm{O}$ uso das amas-de-leite, por parte das famílias senhoriais, estava tão arraigado na sociedade que até mesmo ex-escravas, quando amancebadas com senhores de posição, empregavam amas para amamentar seus filhos. As senhoras negras forras procuravam trajar-se e comportar-se como a sociedade dita branca, numa tentativa de serem mais facilmente aceitas. Uma dessas ex-escravas foi Chica da Silva, que viveu na região de Diamantina no século XVIII e fez uso de amas-de-leite. Chica teria amamentado apenas seu primeiro filho, pois tivera o menino muito jovem, quando ainda era escrava. Após a mudança de sua condição social, quando já vivia com o contratador de diamantes, o branco João Fernandes, Chica teve 13 filhos em 15 anos, todos aleitados por amas. Todos eles sobreviveram à infância, e poucos não chegaram à idade adulta, mas consta que alguns bebês de escravas que amamentaram os filhos de Chica morreram ainda pequenos. Duas dessas escravas que perderam seus bebês foram libertadas por Chica em testamento, por gratidão e reconhecimento (quem sabe, também por tentativa de compensação por suas perdas). Como Chica da Silva e João Fernandes possuíram muitos escravos, é possível que sempre houvesse alguma escrava com bebê pequeno quando nascia um filho do casal, e assim o problema da amamentação de sua prole era resolvido facilmente. E mais: Chica pode ter permitido a dupla amamentação em alguns casos ou mesmo em todos (Furtado, 2003).

${ }^{5}$ Isso até a promulgação das leis de 15 de setembro de 1869 e 28 de setembro de 1871 . A primeira proibia a desagregação da família escrava pela comercialização em separado de seus membros, e a última vedava a venda da mãe sem seus filhos menores de 12 anos. Sobre o assunto, ver Reis, 2001, p.61.

${ }^{6}$ A mulher deveria ser examinada minuciosamente por um médico e aprovada como sadia e capaz para ser uma ama-de-leite. O movimento pelo aleitamento materno chegou ao Brasil seguindo ideias vigentes na França já desde finais do século XVIII, trazidas por médicos brasileiros que se haviam formado naquele país. Muitos dos textos aqui publicados eram traduções dos que apareciam nos periódicos franceses.

7 Esse tema era objeto de constante discussão nas teses dos doutores em medicina da época. Sobre o assunto ver, entre outros, Alencastro, 1997.

${ }^{8}$ As teses dos médicos oferecem vasta lista de doenças. Sobre o assunto, ver Costa, 1983, p.163 e Graham, 1992, p.130-131, entre outros.

${ }^{9}$ Janet Golden (2001, p.144-145) menciona amas que pegaram sífilis de bebês nos EUA, e acrescenta que, naquele país, em meados do século XIX, quando os médicos passaram a inspecionar as amas com mais frequência, procuravam localizar entre elas as sifilíticas, para amamentar bebês com sífilis congênita. Valerie Fildes (1988, p.74), por sua vez, afirma que quando não era possível encontrar alguma ama nessa condição, um animal era destacado para amamentar o bebê.

${ }^{10} \mathrm{Na}$ década de 1890 circulou, também na cidade do Rio de Janeiro, outra revista voltada especificamente para a valorização da maternidade como algo promotor de satisfação, O Quinze de Novembro do Sexo Feminino (1892-1896) (Graham, 1992, p.144).

11 Referindo-se à amamentação nos EUA, nos séculos XVIII e XIX, Janet Golden (2001, p.13) observa ainda que, para os mais pobres (famílias que para se manter dependiam também dos rendimentos do trabalho da mulher), mandar o bebê para a casa de uma ama significava a possibilidade de a mãe retornar ao trabalho e que, muitas vezes, essa decisão era imposta à mulher pelo marido ou por outro membro da família.

${ }^{12}$ Em sua dissertação de mestrado, Rafaela de Andrade Deiab (2006) analisa a figura da mãe-preta nos textos de literatura brasileira e explora a noção, de então, da 'mãe escrava infeliz' porém 'ama-de-leite realizada', seguindo o rastro de autores de fins do século XIX e início do XX, como Mello de Moraes Filho (poeta abolicionista) e Augusto dos Anjos (poeta), entre outros.

${ }^{13}$ Luiz Felipe de Alencastro (1997, p.439-440) escreveu um pequeno texto sobre essa foto, bem colocado no epílogo de seu livro, e conclui observando a união das duas personagens retratadas: "Uma união fundada no amor presente e na violência pregressa. Na violência que fendeu a alma da escrava, abrindo o espaço afetivo que está sendo invadido pelo filho de seu senhor ...".

${ }^{14}$ Sobre a representação de forros e escravos em fotografias no século XIX, ver Koutsoukos, 2007 .

${ }^{15}$ Sobre a foto de Mônica e outras amas retratadas em estúdios fotográficos no Brasil da segunda metade do século XIX, ver Koutsoukos, 2007b.

${ }^{16}$ Processo (ANRJ - Corte de Apelação: mç. 215, n. 215, gal.C), citado em Cavalcanti, 2004, p.187-189.

${ }^{17} \mathrm{O}$ costume de fotografar crianças brancas com suas amas-de-leite ou amas-secas negras foi comum nos Estados Unidos. É possível encontrar numerosas fotos desse tipo nos livros sobre a história da fotografia 
daquele país. Contudo desconheço fotos com esse tema produzidas na Europa. Da França, localizei numerosas gravuras que exploraram o tema em jornais e revistas, enquanto ferviam os debates sobre a amamentação 'mercenária' e o incentivo às 'novas mães', mas em todas as gravuras francesas a que tive acesso só amas brancas são retratadas (ver Sussman, 1982).

\section{REFERÊNCIAS}

ALENCASTRO, Luiz Felipe de (Org.). Império: a corte e a modernidade nacional. São Paulo: Companhia das Letras. (História da Vida Privada no Brasil, 2). 1997.

APPLE, Rima D.

Mothers and medicine: a social history of infant feeding, 1890-1950. Madison: University of Wisconsin Press. 1987.

BARDI, Pietro Maria.

Apresentação. Gênios da pintura. v.2: Da Renascença ao Maneirismo. São Paulo: Abril Cultural. s.d.

BRETAS, Agostinho Joze Ferreira.

A utilidade do alleitamento maternal e os inconvenientes que resultão do despreso deste dever: these, Faculdade de Medicina do Rio de Janeiro. Rio de Janeiro: Typographia e Livraria de J. Cremière. 1838.

CASTILHO, Ildefonso Archer de.

Hygiene da primeira infancia: these, Faculdade de Medicina do Rio de Janeiro. Rio de Janeiro: Typographia Universal de Laemmert \& Companhia. 1882

CAVALCANTI, Nireu Oliveira.

Crônicas: histórias do Rio colonial. Rio de Janeiro: Civilização Brasileira. 2004.

CERQUEIRA, Nicolau Barbosa da Gama. Hygiene da primeira infancia: these, Faculdade de Medicina do Rio de Janeiro. Rio de Janeiro: Typographia de José Neves Pinto. 1882.

CHALHOUB, Sidney.

Machado de Assis historiador. São Paulo: Companhia das Letras. 2003.

COSTA, Jurandir Freire.

Ordem médica e norma familiar. 2.ed. Rio de Janeiro: Graal. 1983.

COSTA, Thomas José Xavier dos Passos Pacheco e. Considerações geraes sobre os cuidados que se devem prestar aos recem-nascidos quando vem no estado de saude, e sobre as vantagens do aleitamento maternal: these. Faculdade de Medicina do Rio de Janeiro. Rio de Janeiro: Typographia Franceza. 1849.

D’ARAUJO, José Augusto Cesar Nabuco. Algumas considerações acerca da utilidade do alleitamento maternal e dos males provenientes do despreso deste grandioso dever: these, Faculdade de Medicina do Rio de Janeiro. Rio de Janeiro: Typographia Universal de Laemmert. 1844.

D’AZEVEDO, Luiz Augusto Corrêa.

Do aleitamento natural, artificial e mixto em geral e particularmente do mercenario em relação ás condições em que se acha no Rio de Janeiro: these, Faculdade de Medicina do Rio de Janeiro. Rio de Janeiro: Typographia Academica. 1873.

DEIAB, Rafaela de Andrade.

A mãe-preta na literatura brasileira: a ambigüidade como construção social (1880-1950). Dissertação (Mestrado em Antropologia) - Universidade de São Paulo, São Paulo. 2006.

EBOLI, Thomaz.

Dissertação sobre hygiene: os prejuizos que causam uma má amamentação: these, Faculdade de Medicina do Rio de Janeiro. Rio de Janeiro: Typographia Popular. 1880.

FILDES, Valerie.

Wet nursing: a history from antiquity to the present. Oxford: Basil Blackwell Inc. 1988.

FURTADO, Júnia Ferreira.

Chica da Silva e o contratador de diamantes: o outro lado do mito. São Paulo: Companhia das Letras. 2003.

GENOVESE, Eugene Dominick.

A terra prometida: o mundo que os escravos criaram I. v.1, Rio de Janeiro: Paz e Terra. 1988.

GOLDEN, Janet.

A social history of wet nursing in America: from breast to bottle. Columbus: Ohio State University Press. 2001.

GRAHAM, Sandra Lauderdale. Proteção e obediência: criadas e patrões no Rio de Janeiro (1860-1910). São Paulo: Companhia das Letras. 1992.

HEFLINGER JR., José Eduardo; LEVY, Paulo Masuti; CANTALICE, Rommel Siqueira Campos (Ed.).

Recordações de infância de Carlota Schmidt no Ibicaba. Limeira: Editora Unigráfica. 2005.

KOSSOY, Boris.

Dicionário histórico-fotográfico brasileiro: fotógrafos e ofício da fotografia no Brasil (1833-1910). São Paulo: Instituto Moreira Salles. 2002. 
KOUTSOUKOS, Sandra Sofia Machado. 'Typos de pretos no estúdio do photographo': Brasil, segunda metade do século XIX. Anais do Museu Histórico Nacional, Rio de Janeiro, n.39, p.455-482. 2007a.

KOUTSOUKOS, Sandra Sofia Machado. Amas na fotografia brasileira da segunda metade do século XIX. Studium, Campinas, Projeto especial Representação Imagética das Africanidades no Brasil. Disponível em: http:// www.studium.iar.unicamp.br/africanidades/ koutsoukos/index.html. Acesso em: dez. 2007. 2007b.

KOUTSOUKOS, Sandra Sofia Machado. No estúdio do photographo, o rito da pose: Brasil, segunda metade do século XIX. Revista Ágora, Vitória, n.5, p.1-25. Disponível em: www.ufes.br/ppghis/agora. Acesso em: out. 2007. 2007c.

KOUTSOUKOS, Sandra Sofia Machado. No estúdio do fotógrafo: representação e autorepresentação de negros livres, forros e escravos no Brasil da segunda metade do século XIX. Tese (Doutorado em Multimeios) - Instituto de Artes, Universidade Estadual de Campinas, Campinas. 2006.

KOUTSOUKOS, Sandra Sofia Machado. Amas-de-leite no estúdio do fotógrafo: Brasil, segunda metade do século XIX. In: Simpósio Nacional de História, 13, 2005, Londrina. Anais da ANPUH. S.I.: s.n. 2005.

LEITÃO, Antonio Gonsalves D'Araujo. Hygiene da infancia: these, Faculdade de Medicina do Rio de Janeiro. Rio de Janeiro: Typographia do Diario. 1840.

LEITE, Miriam Moreira. Retratos de família. São Paulo: Edusp. 2000.

MOURA, Francisco José Coelho de. Do aleitamento natural, artificial e mixto em geral e em particular do mercenario attentas ás condições da cidade do Rio de Janeiro: these, Faculdade de Medicina do Rio de Janeiro; Rio de Janeiro: Typographia Carioca. 1874.

NEVES, Augusto José Pereira das.

Meu nascimento e factos mais notaveis da minha vida [1835-1900]. Cópia do manuscrito em posse de Maria Cristina Volpi Nacif. s.d.

\section{POSTURAS MUNICIPAES..}

Posturas municipaes da capital para o serviço de criados e amas de leite decretadas sobre proposta do chefe de policia Manoel Juvenal Rodrigues da Silva - Juiz de Direito. São Paulo: Typographia A Vapor de Jorge Seckler \& Companhia. No Arquivo Nacional, encontrase na Série Justiça - GIFI: 5B 543. 1886.

\section{PRADEZ, Charles.}

Nouvelles études sur le Brésil. Paris: Ernest Thorin Editeur. 1872.

PRIORE, Mary Del (Org.).

História das crianças no Brasil. São Paulo: Contexto. 1999.

REIS, Celso Eugenio dos. Do aleitamento natural, artificial e mixto em geral, e em particular do mercenario em relação ás condições da cidade do Rio de Janeiro: these, Faculdade de Medicina do Rio de Janeiro. Rio de Janeiro: Oliveira e Silva. 1882.

REIS, Isabel Cristina Ferreira dos. Histórias da vida familiar e afetiva de escravos na Bahia do século XIX. Salvador: Editora da Universidade Federal da Bahia. 2001.

SCHWARCZ, Lilia Moritz e REIS, Letícia Vidor de Souza (Org.).

Negras imagens: ensaios sobre cultura e escravidão no Brasil. São Paulo: Editora da Universidade de São Paulo. 1996.

SILVA, João Baptista Monteiro da. $\mathrm{Da}$ alimentação nas primeiras idades: estudo critico sobre differentes methodos de aleitamento: these, Faculdade de Medicina do Rio de Janeiro. Rio de Janeiro: Typographia de Leuzinger \& Filhos. 1884.

SUSSMAN, George D.

Selling mother's milk: the wet-nursing business in France, 1715-1914. Chicago: Urbana. 1982.

VENÂNCIO, Renato Pinto.

Maternidade negada. In: Del Priore, Mary (Org.). História das mulheres no Brasil. São Paulo: Contexto. p.189-222. 2002.

\section{$\rightarrow \rightarrow+<<$}

